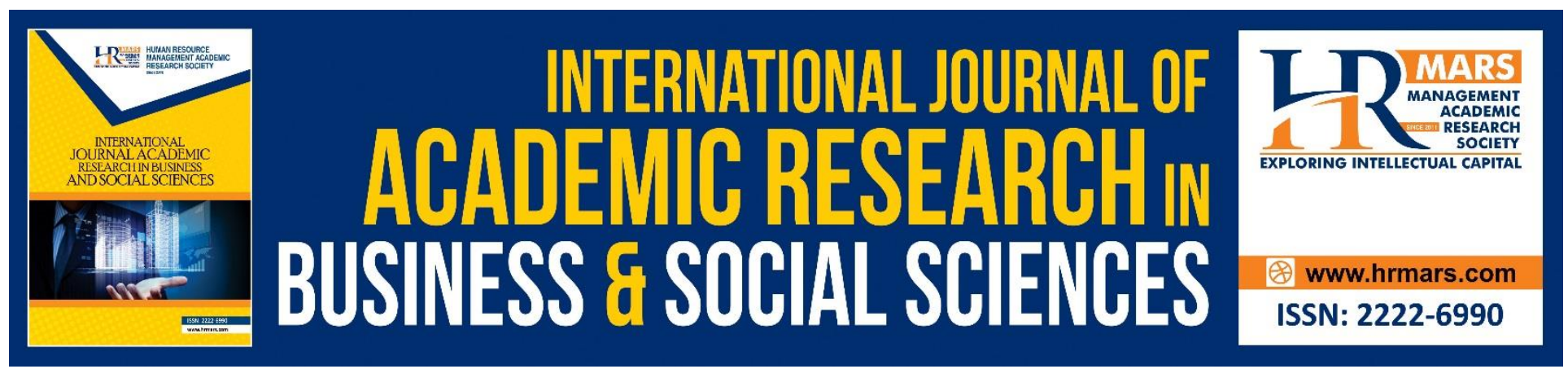

\title{
Leaders' Willingness to Sacrifice: A phenomenology of Batik Entrepreneurs in Surakarta
}

Sarjiyanto, Sarwoto, Joko Suyono \& Norafzan Awang

To Link this Article: http://dx.doi.org/10.6007/IJARBSS/v9-i1/5516 DOI: $10.6007 /$ IJARBSS/v9-i1/5516

Received: 02 Dec 2018, Revised: 04 Jan 2019, Accepted: 13 Jan 2019

Published Online: 19 Jan 2019

In-Text Citation: (Sarjiyanto, Sarwoto, Suyono, \& Awang, 2019)

To Cite this Article: Sarjiyanto, Sarwoto, Suyono, J., \& Awang, N. (2019). Leaders' Willingness to Sacrifice: A phenomenology of Batik Entrepreneurs in Surakarta. International Journal of Academic Research in Business and Social Sciences, 9(1), 1121-1133.

Copyright: (C) 2019 The Author(s)

Published by Human Resource Management Academic Research Society (www.hrmars.com)

This article is published under the Creative Commons Attribution (CC BY 4.0) license. Anyone may reproduce, distribute, translate and create derivative works of this article (for both commercial and non-commercial purposes), subject to full attribution to the original publication and authors. The full terms of this license may be seen

at: http://creativecommons.org/licences/by/4.0/legalcode

Vol. 9, No. 1, 2019, Pg. 1121 - 1133

http://hrmars.com/index.php/pages/detail/IJARBSS

JOURNAL HOMEPAGE

Full Terms \& Conditions of access and use can be found at http://hrmars.com/index.php/pages/detail/publication-ethics 


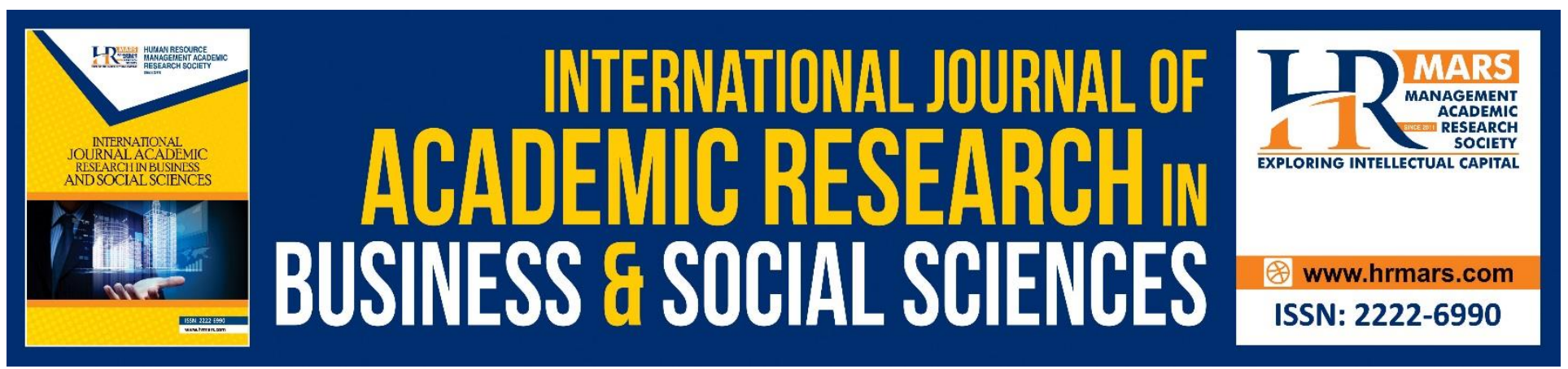

\title{
Leaders' Willingness to Sacrifice: A phenomenology of Batik Entrepreneurs in Surakarta
}

\author{
Sarjiyanto ${ }^{1}$, Sarwoto ${ }^{1}$, Joko Suyono ${ }^{1} \&$ Norafzan Awang ${ }^{2}$ \\ $1^{*}$ Department of Economics, Faculty of Economy and Business, University of \\ Sebelas Maret, Indonesia. \\ Address: Ir Sutami No. 36A. Kentingan 57125 Surakarta, Central Java, Indonesia \\ ${ }^{2}$ Faculty of Economic and Management. University College Bestari, Setiu, Terengganu, Malaysia \\ 2Email :afzan@ucbestari.edu.my
}

\begin{abstract}
This paper discussed a leader's willingness to sacrifice. The purpose of this study was to develop a model of leader's willingness to make sacrifices in accordance with the values of local wisdom. This paper was conducted to explore the meaning of a leader's willingness to sacrifice. It's qualitative paper with a phenomenological approach to explore the leader's willingness to sacrifice among batik entrepreneurs in Surakarta. The batik industry was chosen because it is one of the unique products that will improve the nation's competitiveness. The results showed that there were nine factors underlying the willingness to sacrifice by a leader in the context of batik entrepreneurs in Surakarta, namely: confidence, dare to take risks, responsibility, respecting history (lara lapa), sincere, preserving culture, customer orientation, liability and spirit to rise.
\end{abstract}

Keywords: leaders, willingness, sacrifice, batik entrepreneur and values of local wisdom

\section{Introduction}

As part of Indonesian culture, batik has high historical value, not only as fashion or commodity, but as visual communication of cultural philosophy and value (Rarick \& Sunaryo, 2013). The batik industry recently faces tighter competition. According to Indonesian Bureau of Statistics, 1,037 tons of Chinese batik worth USD\$30 million was imported to Indonesia (www.kemenperin.go.id, 2012). To be able to compete with other countries, the industries should continuously improve their competitiveness. This effort is done by looking inside the industry on its human resource aspect and adopting practices with values and uniqueness. Every organization has unique human resource competence (Barney, 1991, 2001). One of the uniqueness is leadership. 
Studies on leadership were focused more on the transformational leadership model than on the transactional leadership model (Bass, 1985; Burns 1978). The transformational leadership model motivates the subordinates to internalize common and bigger values and objectives (Bass, 1995; Burns, 1978). This leadership tradition highlights charismatic leadership which directly focuses on the importance of a certain leadership aspect, i.e. "the leader's willingness to sacrifice" (Conger \& Kanungo, 1998). This behavior contributes substantially on the effectiveness of the leadership (Choi \& Mai-Dalton, 1998), and the leader's willingness to sacrifice is an important component in the charismatic leadership (Conger \& Kanungo, 1987; Yorges et al., 1999).

The model was first empirically elaborated by Choi \& Mai-Dalton (1999). They show that the willingness to sacrifice improves transformational quality perception and that a leader with such willingness is more influential than that with no willingness. Other studies confirm the relationship between the willingness and a leader's effectiveness. Yorges et al., (1999) state that a sacrificing leader will be perceived as more charismatic and could motivate the subordinates better to contribute in charities. Furthermore, De Cremer (2002) and De Cremer \& Knippenberg (2002) also show that the willingness will result in better subordinates' performance.

On the other hand, organizations nowadays focus more on improving transformational leadership for their managers because it will result in better organizations' performances (Waldman et al., 2001). One of the variables to improve transformational leadership is the leaders' willingness to sacrifice (Choi \& Mai Dalton, 1999; De Cremer \& van Knippinberg, 2002, 2004; Yorges et al., 1999). Previous studies show that the willingness to sacrifice influences the subordinates by encouraging reciprocal norms (Choi \& Mai Dalton, 1999) by projecting the leader as the example (Shamir et al. 1993), and by projecting the personal needs that the leader is closely related with the vision (Avolio \& Locke, 2002).

The inconsistencies on research findings about the leader's willingness to sacrifice are indicated to happen because of the differences in research contexts, especially local contexts. On the other hand, there are still a few empirical studies discussing the model of a leader's willingness to sacrifice that is in accordance with local wisdom values. In this case, the form of willingness might be different between west and east. The Western concept of leadership highlights competition, meanwhile the Eastern leadership suggests cooperation. The Western leadership concept focuses on mind and rationale, while Eastern leadership is based on wisdom. Therefore, it is crucial to develop a model of leaders' willingness to sacrifice that is based on the local context and in accordance with local wisdom values.

This research was qualitative in nature and employed phenomenology method. The phenomenology method is not only a study that tries to describe behaviors (shown in attitude, expression, and or discussions between subjects) in detail, holistically and contextually, but it also tries to explicate the meanings behind the phenomena, that are noumena which are in line with local wisdom values.

This study was conducted specifically on batik industries which recently faced tighter competitions. Batik is one of the products that have uniqueness to elevate the nation's 
INTERNATIONAL JOURNAL OF ACADEMIC RESEARCH IN BUSINESS AND SOCIAL SCIENCES

Vol. 9, No. 1, Jan, 2019, E-ISSN: 2222-6990 @ 2019 HRMARS

competitiveness.

\section{Literature Review}

\section{Leaders' Willingness to Sacrifice}

Leaders could be categorized into two, transactional and transformational leaders. Transactional leaders take initiative in contacts with the subordinates by exchanging something valuable. On the contrary, transformational leaders attracts subordinates tow ord higher moral values (Burns, 1978).

The influence of transformational leadership process is through internalization; the subordinates tend to accept (internalize) the interesting vision promoted by the leader. A vision becomes interesting to the subordinates when it is in line with their values and principles (Dvir and Shamir, 2003). A leader could elevate the subordinates' commitment to his vision through the willingness to sacrifice. This willingness contributes to many important things, such as charismatic perception, reciprocal norm, contribution on public's goodness, willingness to show extra effort, willingness to be part of a group, and attributions done on the leader's behavior (Choi \& Mai-Dalton, 1999; De Cremer \& van Knippenberg, 2002, 2004; Halverson et al., 2004; Yorges et al., 1999).

Most literatures suggest that the willingness to sacrifice shows one's disposition to "suffer certain loss to preserve personal belief and value" (Yorges et al., 1999) and it is acknowledged as common practice done by great leaders (Burn, 1978). The concept of leaders' willingness to sacrifice shows a similarity with an approach in which the leader leads by serving others (Greenleaf \& Spear, 2002), although there is no clear indication of the leaders' benefit (Avolio \& Locke, 2002).

The concept of leaders' willingness to sacrifice shows that a leader is willing to take risks personally to achieve the objective or mission of a certain group or organization (Conger \& Kanungo, 1987). The willingness improves the subordinates' feeling and perception as well as dependencies. In this case, the leader with such willingness is evaluated as charismatic and interesting, as well as a perfect example (Conger \& Kanungo, 1987). The other concept of leaders' willingness to sacrifice defines this leadership as 'the total/partial omission and/or permanent deferment of personal interest, privilege or prosperity in labor division, reward distribution, and power application' (Choi \& Mai Dalton, 1998). This statement is supported by Yorges et al. (1999) who define the willingness as 'giving up or losing something important'. The point highlighted here is that both definitions focus on 'giving up personal benefit'. On the other hand, De Cremer \& Knippenberg (2004) see this construct in a wider perspective by including benefits taken by other parties if a leader is willing to sacrifice. They define the willingness as a leader's disposition to 'spend personal expense (or bear the cost) to achieve the objective or mission of a certain group or organization'.

Transformational leaders are those who are willing to sacrifice for the common good (Bass \& Steidlmeier, 1999). Such willingness builds trust, receives public acceptance, and helps in shaping community. Smith et al., (1983) state that the willingness focuses on 'personal sacrifice'. Meanwhile, Singh \& Khrishnan (2008) in agreement with Choi \& Mai Dalton (1998) operationalize and define the willingness as the action of omission or deferment of personal interest, privilege, and prosperity.

\section{The Measurement of Leaders' Willingness to Sacrifice}

Some previous studies has identified indicators to measure leaders' willingness to sacrifice (Table 1). 
INTERNATIONAL JOURNAL OF ACADEMIC RESEARCH IN BUSINESS AND SOCIAL SCIENCES

Vol. 9, No. 1, Jan, 2019, E-ISSN: 2222-6990 @ 2019 HRMARS

Table 1

Measurement of Leaders' Willingness to Sacrifice

\begin{tabular}{|l|l|l|l|}
\hline No & \multicolumn{1}{|c|}{ Researcher } & \multicolumn{1}{|c|}{ Dimension } & \multicolumn{1}{c|}{ Indicator } \\
\hline 1 & $\begin{array}{l}\text { Conger \& Kanungo } \\
(1987)\end{array}$ & $\begin{array}{l}\text { Providing one dimension of leaders' } \\
\text { willingness to sacrifice }\end{array}$ & $\begin{array}{l}\text { Proposing two } \\
\text { questions }\end{array}$ \\
\hline 2 & $\begin{array}{l}\text { Choi \& Mai Dalton } \\
(1999)\end{array}$ & $\begin{array}{l}\text { Developing a model of leaders' } \\
\text { willingness to sacrifice which consists } \\
\text { of one dimension }\end{array}$ & $\begin{array}{l}\text { Developing 13 } \\
\text { questions }\end{array}$ \\
\hline 3 & $\begin{array}{l}\text { Singh \& Khrishnan } \\
(2008)\end{array}$ & $\begin{array}{l}\text { Providing two dimensions, but the } \\
\text { second dimension consists of items } \\
\text { with low reliability that should be } \\
\text { omitted so only one dimension that } \\
\text { could be used }\end{array}$ & $\begin{array}{l}\text { Developing six } \\
\text { questions }\end{array}$ \\
\hline
\end{tabular}

Conger et al., (2000) found that showing willingness to sacrifice results in positive influence on the subordinates' respect to the leader. Such willingness leads to giving in and creating an egoistic cultures in organizations (Choi \& Mai-Dalton, 1999). Based on Table 1 above, it can be seen that the previous studies result in inconsistence findings which were indicated as a result of the studies' contextual differences.

\section{Research method \\ Research Design}

This research was a qualitative study with a phenomenology approach. The assumption of employing phenomenology is that individuals in interacting with others will give various meanings. The meaning of experiences forms realities performed by individuals (Waters, 1994; Dimyati, 2000; Collin, 1997). This phenomenology approach studies the meaning conceptualized by individuals, which is then expressed in phenomena and tries to answer the question of what a certain phenomenon means to the individual (Ritzer, 1992). The phenomenology approach in a qualitative study states that to understand someone's behavior, it is related to various kinds of motives (Schutz, 1972). The steps in this phenomenology study refer to the steps proposed by Fatchan (2013). This statement emphasized by Creswell (2013) to illustrate the phenomenonical analysis is where researchers continue with the "horizontalization" of data. This refers to the process wherein the researchers lists each of the relevant quotes of the studied topic and gives them equal value with regard to the expressions of the group. This is where the textual description begins: what are the participants saying? What are the relevant topics expressed by the research participants? Then the researcher writes the textual description and includes "ad verbatim" quotations.

\section{Population, sample and sampling technique}

The population of this research are batik entrepreneurs in Surakarta. The sampling technique of this study employed purposive sampling technique with consideration that the number of owners 
in the companies is not the same. The samples were taken from those who were willing to participate in this study and the sampling stopped when the last sample did not provide new information on the research topic. The total number of entrepreneurs who became the respondents of this study was four people.

\section{Type of Data}

This research used data taken from primary source through direct interviews with the respondents and active participation in the respondents' business during the data and information gathering stage.

\section{Findings and discussion}

\section{Informants/Process of Finding the Informants}

In finding the informants, the researcher tried to find batik entrepreneurs in Surakarta who are willing to share their experiences in preserving their business in the midst of difficult conditions through snowballing (Neuman, 2009: 220). The process was done by using reference from one informant who recommended the next competent informant to provide relevant information for the study. Meanwhile, for the sampling method, the researcher employed purposive sampling, in which the researcher by design search for several batik entrepreneurs for this study. The main purpose of sampling in qualitative studies is to find specific cases, events or behaviors to clarify certain context (Neuman, 2009: 219). The respondents participated in this study were:

1. Informant 1 is a neighbor of one of the researchers' parents-in-law who is a batik entrepreneur from Boyolali. The good relationship between the researcher and the informant began with the frequent interaction between them since the informant is the researcher's parents-in-law's best friend who also joins the same Koran recitation group. The informant has been an entrepreneur for more than 25 years. She started from zero, from being a retailer who now bought batik from bigger entrepreneurs to a business owner who has her own production unit.

2. Informant 2 is the founder of Batik Mayaratna in Mojosongo, Surakarta. The researcher interviewed her in one of the charity gatherings of Lions Club Solo Putri. She runs a beauty salon and batik business by building both conventional and online shop.

3. Informant 3 established handmade batik in Penumping Solo inheriting the business, initiated by Eyang Broto. The business has been running for more than 25 years supplying batik to entrepreneurs in Jakarta and other areas through social media.

4. Informant 4, a brother of one of the researchers, is an entrepreneur who is running a family-owned batik business that has been running for generations in one of the batik centers in Solo, namely Laweyan. The kinship between the informant and the researcher is very helpful in the effort of understanding the psyche of the informant. In Laweyan, the batik industry is establish since the industries existed even before the city was established and continued from generation to generation. 


\section{Data Analysis and Data Analysis Procedure}

This part provides in-depth explanation on the procedure used in this study. This explanation provides information on how the data analysis was conducted and shows how the themes were extracted. The in-depth analysis covers short repetition of data analysis procedure implemented and is followed by specific examples from the data. The themes extracted described important general and essential experiences from the informants in terms of their willingness to sacrifice.

The data analysis process followed Fatchan's procedures (2013) which cover: 1) conducting general observation, 2) deciding focus and subject as well as the informants, 3) conducting participation observation, 4) conducting observation on discussions among research subjects, 5) conducting description analysis and data validation, 6) conducting in-depth interviews in form of dialogs with research subjects, 7) conducting substantial analysis and data validation, 8) extracting the subjects' meaning, 9) understanding the subjects' meaning. The essence of this data was wordby-word quotations from the informants and in general was represented by the dimension presented.

In one or two weeks after each interview, the researcher finished transcribing the interview. Every transcript was verified for its accuracy and the researcher read over and over to be able to internalize the meaning in the interview completely. The data analysis was started when the researcher examined the transcript and isolated significant statements from each participant. The comprehensive narration description of each informant then was analyzed to become dimensions and indicators. Appendix 1 provides short version of narrative description for each informant and the corresponding themes. The themes from all informants were analyzed and some similarities were gathered to extract the main themes that represented all informants.

\section{The phenomenology of leaders' willingness to sacrifice Confidence}

The business deterioration experienced by batik entrepreneurs in Surakarta did not deter them. The underlying reason they were struggling to be better was confidence. This could be seen from the first informant's statement as follows.

"In facing problems, my thought is simple, "every business could experience deficit." The second is when some of my friends close their business and change to other business (usually because they are running out of money, goods, etc.) I will not follow them changing lines of business. In my mind and heart, I say "I have done this for long time.

Based on the description above, researchers proposed the following proposition:

P1. Confidence is the cause of the leaders' willingness to sacrifice in batik industries in Surakarta. 


\section{Dare to Take Risks}

The other reason why the entrepreneurs were willing to sacrifice for the sustainability of their business was their business instinct. That instinct is close to the willingness to take risks. This can be seen in the first informant's statement as follows.

"The thing I think about is how I keep running the business and my employees are not leaving or fired. That is, it is too bad if the employees are leaving because the market is stagnant. I return to the initial thought I said, "every business could experience loss". In addition, my bad feeling was also based on the feeling and the assumption that the employees that I have are not just employees, I consider them as my "children". If we are happy so everybody is happy, and when everything is hard we understand one another well."

Based on the description above, researchers proposed the following proposition:

P2. Dare to take risks is the cause of the leaders' willingness to sacrifice in batik industries in Surakarta.

\section{Attachment}

The entrepreneurs were willing to sacrifice to continue the business because they have strong feeling of attachment to the business. This can be seen in the first informant's statement as follows.

"The point is batik is my life that is inherent with my life. So, I extremely hope that my children continue the business, and thank God, my oldest son has started opening business gradually (he also is my merchant)."

They consider the business as being attached to them. The job they do was an important aspect in their lives, not only for the sake of money but an inseparable bond.

Based on the description above, researchers proposed the following proposition:

P3. Responsibility is the cause of the leaders' willingness to sacrifice in batik industries in Surakarta.

\section{Respecting History (lara lapa)}

The other background that became the reason why they struggled was their propensity to respect history.

"It is clear that the efforts have led me up to this kind of life. At first my father (deceased) and I had the determination, the most important is working without considering the benefit. It turned out that with diligence, sincerity, and love, the benefit was beyond our forecast when we did not have anything. At that time, my father was only a driver and after undergoing this effort, thank God, he could pay for schools, have a home, etc. Now we have stamp and embroidery businesses, and our employees could also have children and they all go to school. This "lara lapa" time cannot be overlooked. I am sincere if I need to sacrifice a lot to maintain this business."

Respecting culture is not only done to memorize the past, but to continue what has been done by the predecessors. For this reason, an entrepreneur will never leave his/her job even though they experience hard times. Their tactical thought was that they have experienced harder times when they 
INTERNATIONAL JOURNAL OF ACADEMIC RESEARCH IN BUSINESS AND SOCIAL SCIENCES

Vol. 9, No. 1, Jan, 2019, E-ISSN: 2222-6990 (C) 2019 HRMARS

started the business. All problems they have now could not be compared to the problems they had finding their path for the business.

Based on the description above, researchers proposed the following proposition:

P4. Respecting culture (lara lapa) is the cause of the leaders' willingness to sacrifice in batik industries in Surakarta

\section{Sincere}

The entrepreneurs' motivation to keep their business was their willingness to sacrifice. This could be seen from informant 2 statement as follow.

"It turned out that with diligence, sincerity, and love, the benefit was beyond our forecast when we did not have anything."

Batik entrepreneurs in Surakarta sacrificed a lot sincerely. They did not cade anything with the business they have. They were willing to do anything to keep the business running. This cannot be separated from the role of the business that has provided a livings for them.

Based on the description above, researchers proposed the following proposition:

P5. Being sincere is the cause of the leaders' willingness to sacrifice in batik industries in Surakarta

\section{Preserving Culture}

An underlying theme the entrepreneurs value to keep their business although they experience hard times was their responsibility to preserve culture which is inherited from their predecessors. This can be seen in the fourth informant's statement as follows:

"Because batik is an inherited business. Laweyan is a batik center in Solo, even before the city existed. Batik from my great-grandparents that I continue made me survive. Batik is also a cultural and family heritage that should not be abandoned let alone forgotten".

From the statement above, this study could be compared to the previous studies in which the leaders could improve the commitment perception towards the vision by looking at the leaders' willingness to sacrifice. The willingness contributes to many important results, such as charismatic perception, reciprocal norm, contribution on public's goodness, willingness to show extra effort, willingness to be part of a group, and attributions done on the leader's behavior (Choi \& Mai-Dalton, 1999; De Cremer \& van Knippenberg, 2002, 2004; Halverson et al., 2004; Yorges et al., 1999). The strong culture creates bond with the subordinates who feel that they belonged to the same group that wanted to preserve their culture. The vision becomes interesting for the subordinates since it is in line with their value and ideal (Dvir and Shamir, 2003). The same vision between the leaders with their subordinates on the importance of preserving culture create a stronger bond to maintain the 
business. The culture also make the leaders stronger in facing critical business situations. They do not easily change direction to other more "prospective" business, but they will struggle to respect the cultural inheritance that they think should not be abandoned or even forgotten. Based on the description above, researchers proposed the following proposition:

P6. Preserving culture is the cause of the leaders' willingness to sacrifice in batik industries in Surakarta.

\section{Customer Orientation}

The next background that motivated batik entrepreneurs to maintain the business was their care to the customers who are the most valuable assets of the industry. There are many family businesses that experience declines in customer's demand since they are not responsive in taking care of the customers' needs. This was an example provided by informants 2 and 3 in developing their business. Informant 2 showed that the way a business could survive is by employing technology (internet), which is by opening online shops. The use of technology also helped a company to survive, by promoting through WhatsApps and Blackberry Messenger as described by informant 3.

"We have supportive business climate to promote batik especially in Solo. I promote batik through WA or BBM. I send Batik pattern pictures so the customer knows the meaning of the patterns. Trend style sometimes is not idealistic, I receive any customer's feedback, and the buyer is our king, right?"

Based on the description above, researchers proposed the following proposition:

P7. Customer orientation is the cause of the leaders' willingness to sacrifice in batik industries in Surakarta.

\section{Liability}

The sustainability of a business that is inherited from the predecessors is something that should be preserved. This encourages the entrepreneurs in Surakarta to be willing to sacrifice for the business.

"There should be someone who will continue a family business, right? Because I am the oldest son, I become the backbone of the family."

A prevailing cultural value in the Javanese community is that preserving culture is obligatory. The predecessors' inheritance is an heirloom that should be taken care of and respected. This motivation leads to the willingness to sacrifice on batik entrepreneurs in Surakarta in their efforts of maintaining the business.

Based on the description above, researchers proposed the following proposition:

P8. Liability is the cause of the leaders' willingness to sacrifice in batik industries in Surakarta. 


\section{Spirit to Rise}

A business owner migrated to Malaysia to work for two years in the attempt to collect funds as well as experience. There, the owner received precious experience which turned him 180 degrees as the change of role was from an owner to an employee. In Malaysia, apparently the owner learned many new skills, including screen printing. After the monetary crisis was over, he went back to Indonesia with funding and experiences from Malaysia. His business is expanding today. From the story of the business owner, it could be seen that the leader's willingness to sacrifice showed one's willingness to "suffer to preserve personal belief and value" (Yorges et al. 1999).

This spirit to rise is similar with the concept of leaders' willingness to sacrifice in which the leaders are willing to take risks personally to achieve the objective and mission of a group or organization (Conger \& Kanungo, 1987). The leader was willing to leave his stagnant business to maintain the sustainability of the business and his subordinates' fate. He was willing to go to another country to get money to support the survival of his batik business in Laweyan. This spirit to rise makes the leader stronger in facing critical conditions as well as him becoming an example to the subordinates, as stated by Conger et al. (2000) who found that the willingness to sacrifice has raised the subordinates' respect towards the leader. This spirit to rise and willingness to sacrifice of a leader will result in giving in and creating an unegoistic culture in the organization (Choi \& Mai-Dalton, 1999).

Based on the description above, researchers proposed the following proposition:

P9. Spirit to rise is the cause of the leaders' willingness to sacrifice in batik industries in Surakarta.

\section{Conclusion and Suggestion}

The conclusion drawn from this research was nine factors influencing batik entrepreneurs in Surakarta to be willing to sacrifice to maintain the sustainability of their business, they are confidence, dare to take risks, responsibility, respecting culture (lara lapa), being sincere, preserving culture, customer orientation, liability and spirit to rise. This can be considered as an example of charismatic and transformational leadership aspects. Additionally, organizations are also constantly looking for new ways to develop leadership skills of their managerial transformation and to help employees feel that they belong to the organization. By offering support and guidance to subordinates, leaders can create similar behavior from subordinates, thereby creating a culture that promotes caring and helpful behavior.

The suggestions for the next studies are as follows, firstly, the research could be done with wider scope for multi-industries so that it could be used to generalize the findings and second is longitudinal study could be conducted to measure the leaders' willingness to sacrifice level from time to time. 
INTERNATIONAL JOURNAL OF ACADEMIC RESEARCH IN BUSINESS AND SOCIAL SCIENCES

Vol. 9, No. 1, Jan, 2019, E-ISSN: 2222-6990 (C) 2019 HRMARS

\section{References}

Avolio, B.J., \& Locke, E.E. (2002), "Contrasting Different Philosophies of Leader Motivation: Altruism versus Egoism", Leadership Quarterly, Vol. 13 pp.169-91.

Barney, J. (1991). Firm Resources and Sustained Competitive Advantage. Journal of Management, 17: 99-120.

Barney, J. (2001). Is The Resource-based View a Useful Perspective for Strategic Management Research? Yes. Academy of Management Executive, 26 : 41-56.

Bass, B.M. (1985), Leadership and Performance beyond Expectation, Free Press, New York, NY.

Bass, B.M. (1995), "Transformational Leadership Redux", Leadership Quarterly, Vol. 6 pp.463-78.

Bass, B.M. and Steidlmeier, P. (1999), "Ethics, Character and Authentic Transformational Leadership Behavior", Leadership Quarterly, Vol. 10 No. 2, pp. 181-217.

Burns, J.M. (1978), Leadership, Harper and Row, New York, NY.

Choi, Y. \& Mai-Dalton, R.R. (1999), “The Model Of Followers' Responses to Self-Sacrificial Leadership: An Empirical Test", Leadership Quarterly, Vol. 10 No. 3, pp. 397-421.

Choi, Y., \& Mai-Dalton, R.R. (1998), "On The Leadership Function of Self-Sacrifice", Leadership Quarterly, Vol. 9 pp.475-501.

Collin, F. (1997). Social Reality, Routledge Simultaneously Published, USA and Canada

Conger, J.A. \& Kanungo, R.N. (1987), "Toward A Behavioral Theory of Charismatic Leadership in Organizational Settings", Academy of Management Review, Vol. 12 pp.637-47.

Conger, J.A. \& Kanungo, R.N. (1998), Charismatic Leadership in Organizations, Sage Publications, Thousand Oaks, CA.

Conger, J.A., Kanungo, R.N. \& Menon, S.T. (2000), "Charismatic leadership and follower effects", Journal of Organizational Behavior, Vol. 21 No. 7, pp. 747-67.

Creswell, J.W. (2013). Qualitative Inquiry \& Research Design: Choosing among Five Approaches. Los Angeles, CA: Sage.

De Cremer, D. \& van Knippenberg, D. (2002), "How Do Leaders Promote Cooperation? The Effects of Charisma and Procedural Fairness", Journal of Applied Psychology, Vol. 87 pp.858-66.

De Cremer, D. \& van Knippenberg, D. (2004), “Leader Self-Sacrifice and Leadership Effectiveness: The Moderating Role of Leader Self-Confidence", Organizational Behavior and Human Decision Processes, Vol. 95, pp. 140-55.

De Cremer, D. (2002), "Charismatic Leadership and Cooperation in Social Dilemmas: A Matter of Transforming Motives?", Journal of Applied Social Psychology, Vol. 32 pp.997-1016.Dimyati, M. (2000), Penelitian Kualitatif; Paradigma, Epistimologi, Pendekatan, Metode dan Terapan, Progrma Pascasarjana Universitas Negeri Malang (UM), Malang. 
INTERNATIONAL JOURNAL OF ACADEMIC RESEARCH IN BUSINESS AND SOCIAL SCIENCES Vol. 9, No. 1, Jan, 2019, E-ISSN: 2222-6990 C 2019 HRMARS

Dvir, T. \& Shamir, B. (2003), “Follower Developmental Characteristics As Predicting

Transformational Leadership: A Longitudinal Field Study”, Leadership Quarterly, Vol. 14 No. 3, pp. 327-44.

Fatchan, A. (2013). Metode Penelitian Kualitatif 10 Langkah penelitian Kualitatif Pendekatan Konstruksi dan Fenomenologi. Universitas Negeri Malang, Malang. Halverson, S.K., Holladay, C.L., Kazama, S.M. \& Quinones, M.A. (2004), "Self-Sacrificial Behavior in Crisis Situations: The Competing Roles of Behavioral and Situational Factors", Leadership Quaterly, Vol. 15 No. 2, pp. 263-75.

Neuman, W. Lawrence. (2006). Social Research Methods. United States of America : Pearson Education, Inc.

Rarick, C. \& Sunaryo, Sinto (2013), Internasional Business : Cases and Exercises. www.amazom 